\title{
An investigation of pressure gradients in the isolated human lung
}

\author{
BARRY HOVELL AND SYLVIA MERCHANT \\ From the Department of Respiratory Diseases, University of Edinburgh
}

In their investigations into bronchospasm, Crofton, Douglas, Simpson, and Merchant (1963), and Douglas, Simpson, Merchant, Crompton, and Crofton (1966a and b) have found that a ratio of endomural bronchial pressure to oesophageal pressure in wheezy patients is frequently above unity. They suggested that this might be due to active bronchial muscle contraction on expiration. In a series of lungs we examined the evidence for an alternative theory of a radial traction effect which could explain their findings. The lung was placed in an airtight jar and inflated and deflated, the pressure excursion (J) inside the jar being recorded. Simultaneously, the endomural bronchial pressure excursion (B) was recorded by means of a specially designed probe. The ratio of these two excursions (B/J ratio) was calculated. A ratio of less than unity was consistently obtained, suggesting a simple pressure gradient in the lung. No evidence of a radial traction effect was found in the size of bronchi $(4 \mathrm{~mm}$.) measured, though of course such an effect could not be excluded in other sizes of bronchi or in bronchioles.

By means of a balloon on a suitably designed probe the changes in pressure on the inner bronchial wall can be measured throughout the respiratory cycle (Crofton, Douglas, Simpson, and Merchant, 1963). At the same time changes in oesophageal pressure during the respiratory cycle can be measured. These pressure excursions may be related to each other as a bronchial endomural/oesophageal pressure ratio. This ratio has been found by Douglas, Simpson, Merchant, Crompton, and Crofton (1966a) to be approximately 0.3 to 0.6 in relatively normal subjects but frequently to be above unity when the subject is wheezy. The difference in the ratio between the 'normal' and the wheezy subject was thought possibly to be due to active contraction of the bronchial muscle on expiration in whezzy patients (Crofton et al., 1963; Douglas et al., 1966a and $b$ ).

Howell, Permutt, Proctor, and Riley (1961) have suggested that during lung inflation the larger pulmonary vessels are dilated whereas the smaller ones are compressed. They proposed a theory of a radial traction effect in the lung which could account for this phenomenon. They further suggest that the postulated effect could occur in bronchi and in bronchioles. If such a theory applied to the bronchi this could explain the existence of ratios over unity by a simple mechanical action. If a model is considered of a cartwheel where the rim represents the pleural surface and the hub a bronchus, then the spokes could represent chains of elastic alveolar walls. The space between two such spokes can be filled in the model with schematic alveoli. If these alveoli are inflated, it is apparent that the pressure within them is acting not only laterally on the alveoli contained within adjacent spokes but over a small area at the hub and outwards over a larger area at the rim. Therefore the result might be a larger total force (pressure $X$ area) acting outwards than inwards. Because the bronchus and pleural surface are in elastic continuity the bronchus might be pulled outwards in proportion to the degree of inflation of the alveoli, and relatively more so than the pleural surface. If a balloon were placed within a bronchus and the lung were inflated a larger pressure excursion might be recorded by the balloon than at the surface of the lung.

An experimental arrangement was designed to examine the possible effect of such a mechanism on the bronchial walls and hence on the bronchial endomural pressure.

\section{METHOD}

SPECIMENS INVESTIGATED (Table I) A series of nine $\frac{\curvearrowright}{\mathbb{D}}$ specimens of lungs or lobes was obtained from the $\varrho$ operating theatre as soon as possible after resection. 
T A B L E I

DETAILS OF PATIENTS

\begin{tabular}{|c|c|c|c|c|c|c|c|c|c|}
\hline$\underset{\text { ject }}{\text { Sub- }}$ & Sex & Age & Occupation & Diagnosis & Associated Conditions & Operation & $\begin{array}{c}\text { Smoking } \\
\text { (cigarettes) }\end{array}$ & $\underset{\text { (ml.) }}{\text { F.E.V.1.0 }}$ & $\begin{array}{l}\text { F.E.V.1.0 } \\
\text { Predicted } \\
\quad \text { (ml.) }\end{array}$ \\
\hline Mi. & $\mathbf{M}$ & 54 & Labourer (jute) & $\begin{array}{c}\text { Carcinoma of } \\
\text { bronchus }\end{array}$ & $\begin{array}{l}\text { Moderate chronic } \\
\text { bronchitis }\end{array}$ & Pneumonectomy & 40/day & 1,500 & 3,280 \\
\hline Mc. & $\mathbf{M}$ & 56 & Railway & $\begin{array}{l}\text { Carcinoma of } \\
\text { bronchus }\end{array}$ & Mild chronic bronchitis & Pneumonectomy & 20/day & 1,900 & 3,200 \\
\hline Ho. & $\mathbf{M}$ & 59 & Barman & $\begin{array}{c}\text { Carcinoma of } \\
\text { bronchus }\end{array}$ & Mild chronic bronchitis & Lobectomy & $30 /$ day & 1,450 & 2,880 \\
\hline Dl. & $\mathbf{F}$ & 56 & Landlady & $\begin{array}{c}\text { Carcinoma of } \\
\text { bronchus }\end{array}$ & Mild chronic bronchitis & Lobectomy & 20/day & 1,720 & 1,760 \\
\hline St. & $\mathbf{M}$ & 75 & Window cleaner & $\begin{array}{l}\text { Carcinoma of } \\
\text { bronchus }\end{array}$ & Mild chronic bronchitis & Lobectomy & Not known & 1,120 & 1,880 \\
\hline Be. & $\mathbf{M}$ & 62 & Blacksmith & $\begin{array}{c}\text { Carcinoma of } \\
\text { bronchus }\end{array}$ & Mild chronic bronchitis & Pneumonectomy & 10 /day & 2,050 & 2,880 \\
\hline G. & $\mathbf{M}$ & 61 & Clerk & $\begin{array}{c}\text { Carcinoma of } \\
\text { bronchus }\end{array}$ & Nil & Lobectomy & $20 /$ day & 2,060 & 2,720 \\
\hline $\begin{array}{l}\text { Mo. } \\
\text { Sc. } \\
\text { Hu. }\end{array}$ & $\underset{\mathbf{F}}{\mathbf{F}}$ & $\begin{array}{l}66 \\
14 \\
51\end{array}$ & $\begin{array}{l}\text { Housewife } \\
\text { Schoolboy } \\
\text { Domestic }\end{array}$ & $\begin{array}{l}\text { Sarcoma of lung } \\
\text { Bronchiectasis } \\
\text { Status } \\
\text { asthmaticus }\end{array}$ & $\begin{array}{l}\text { Nil } \\
\text { Nil } \\
\text { Nil }\end{array}$ & $\begin{array}{l}\text { Pneumonectomy } \\
\text { Lobectomy } \\
\text { Lung- } \\
\text { post mortem }\end{array}$ & $\underset{\text { Nil }}{\mathrm{Nil}}$ & $\begin{array}{l}1,900 \\
2,250 \\
2,000\end{array}$ & $\begin{array}{l}1,640 \\
2,240 \\
2,160\end{array}$ \\
\hline
\end{tabular}

The lungs were removed in most cases because of carcinoma of the bronchus. One lung was obtained at necropsy 24 hours after death. The lung specimens obtained at operation were investigated experimentally between 10 minutes and one hour after resection.

APPARATUS A plastic connector of suitable size was tied into the main or lobar bronchus. Four long-stay sutures were inserted in the tissue around this bronchus. The specimen was then placed in a glass jar of 9 litres capacity and the stay sutures were threaded through a central hole in the lid of the jar (Fig. 1). The lung was suspended by the sutures so that it hung freely in the jar. The connector fitted snugly into the central hole in the $6 \mathrm{~mm}$. thick Perspex lid, and in addition the junction of the lid and connector was sealed with plasticine to make a fully airtight joint. Another hole in the lid allowed the passage of a needle of $1 \mathrm{~mm}$. internal diameter which was connected to an apparatus for recording the pressure within the jar. A third hole in the lid carried a glass tube of $4 \mathrm{~mm}$. internal diameter to which could be attached a vacuum pump for evacuating air from the jar. The Perspex lid was tightly fixed to the jar by means of four clamps to which the stay sutures were attached. The union between the rim of the jar and the lid was made airtight with Vaseline.

A specially designed bronchial probe (Fig. 2) of the type used in in vivo investigations (Douglas et al., 1966a) was then passed through the connector into the main bronchus until it wedged tightly in a peripheral bronchus. The site of wedging varied, depending on the specimen of lung received. The probe consisted of a double-channelled metal tube which had two solid rubber cuffs at the distal end. A balloon was formed by tying a length of Paul's tubing over the probe so as to cover the rubber cuffs (for full details see Crofton et al., 1963). The balloon and its channel were filled with saline, connected to a Statham pressure transducer, and set to a pressure of $+10 \mathrm{~cm}$. of water. The second channel of the probe was only used to provide a means of allowing air to pass to the lung supplied by the bronchus containing the balloon.

The pressure inside the jar but outside the lung was recorded by means of an open-ended, air-filled polyethylene tube, $1.5 \mathrm{~mm}$. in bore, connected to the needle in the Perspex lid and to a Statham strain gauge. Pressure traces were recorded with a Devices multichannel apparatus.

The probe system was saline-filled, whereas the jar pressure-recording system was air-filled. It was found by experiment that the lag in the saline-filled system was $1 / 50$ th second compared with the air-filled system, and that the two systems always recorded exactly the same pressure excursion for a given applied pressure. The rubber cuffs on the probe ensured that the probe was wedged in approximately the same size of bronchus (approximately $4 \mathrm{~mm}$. in internal diameter) in every cass. Before insertion the balloon was inflated to a pressure of $10 \mathrm{~cm}$. of water. When the probe had been wedged the recording system was adjusted to give a full-scale deflection of either 50 or $100 \mathrm{~cm}$. water.

PROCEDURE With the lung in position in the jar, an attempt was made to pass a suction catheter down the bronchial tree in order to remove as much secretion as possible. This was sometimes difficult in proximally situated tumours. The vacuum pump was attached to the glass tube and a partial vacuum was created in the jar so as to expand the lung as fully as possible (it had usually partially collapsed from handling during surgery and the setting up of the preparation). The pump was then disconnected, the pressure in the jar rose to atmospheric, and the specimen returned to its resting position.

The vacuum pump was intermittently connected to and disconnected from the glass tube at rates of one in $1 \frac{1}{2}$ minutes to 20 per minute, so as to obtain different negative pressures within the vessel. When 


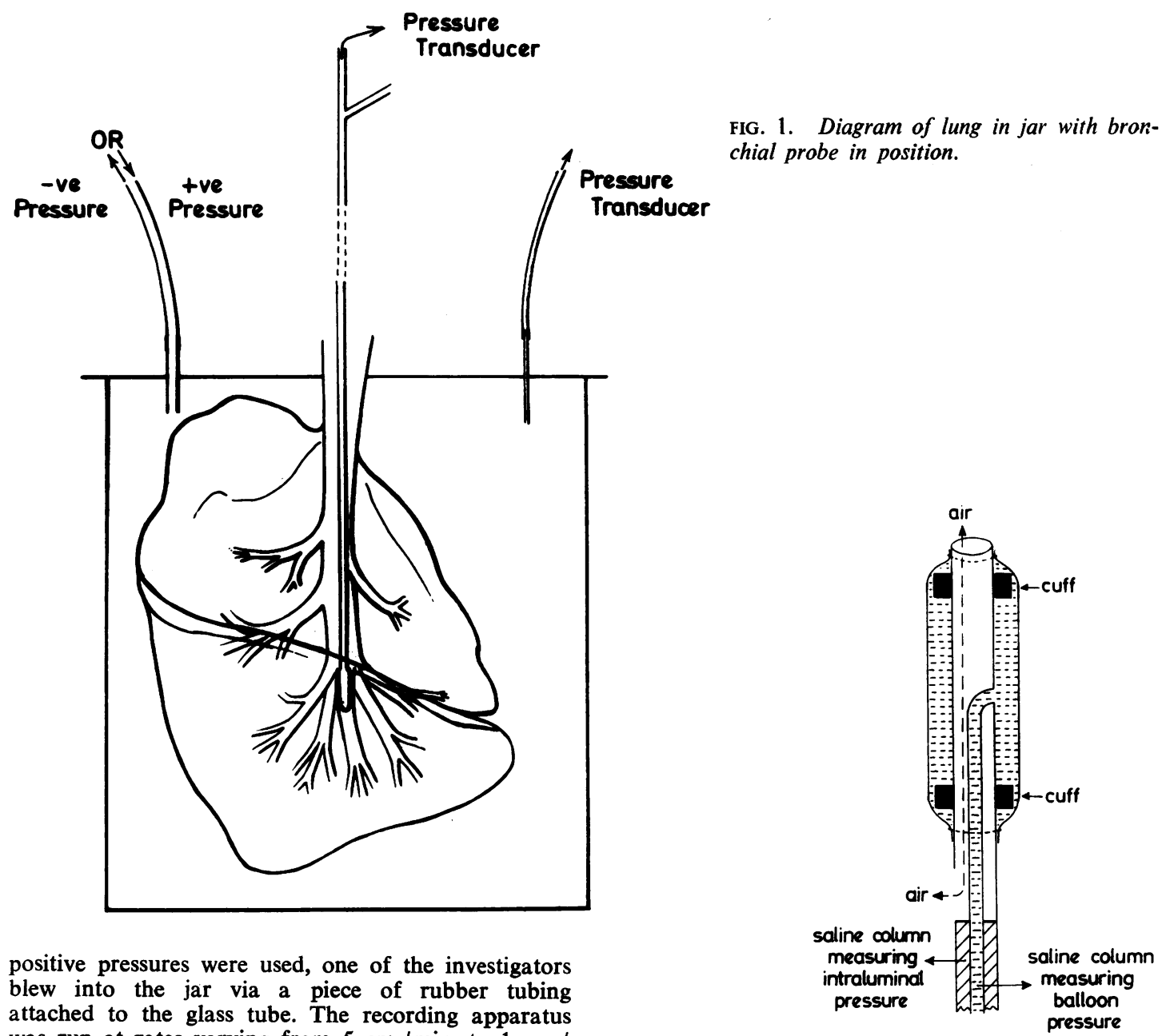

attached to the glass tube. The recording apparatus was run at rates varying from $5 \mathrm{~cm} . / \mathrm{min}$. to $1 \mathrm{~cm}$./ second. By this means a series of tracings was obtained of the balloon pressure excursion inside the bronchus and the pressure excursions inside the jar but outside the bronchus and lung.

In three cases, after a suitable tracing had been obtained, the lung was removed from the jar with the probe in situ, and the bronchus which contained the probe was located by touch. The surrounding parenchyma was then gently dissected away from that particular bronchus and the specimen was replaced in the jar as before. The experiment was then repeated with the bronchus containing the probe deprived of surrounding lung substance.

\section{RESULTS}

In the 10 experiments the ratio of balloon pressure excursion (B) to the applied pressure excursion (J) was always less than unity (Tables II, III, and

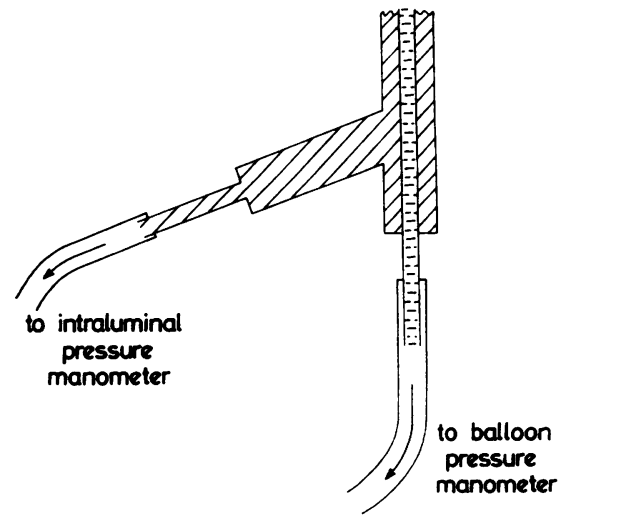

FIG. 2. Diagram of bronchial probe. (Intraluminal saline-filled column not used in these experiments.) 
T A B L E I I

EFFECT OF NEGATIVE JAR PRESSURES ON BRONCHIAL BALLOON PRESSURE AND BALLOON/JAR PRESSURE RATIO

\begin{tabular}{|c|c|c|c|c|c|c|c|}
\hline \multirow[b]{2}{*}{ Subject } & \multicolumn{2}{|c|}{$\underset{(J)}{\text { Jar Pressure Range }}$} & \multicolumn{2}{|c|}{$\begin{array}{c}\text { Corresponding Bronchial Balloon } \\
\text { Pressure Range (B) }\end{array}$} & \multirow[b]{2}{*}{$\begin{array}{l}\text { No. of } \\
\text { Observations }\end{array}$} & \multirow{2}{*}{$\begin{array}{c}\text { Mean } \\
\mathbf{B} / \mathbf{J} \\
\text { Ratio }\end{array}$} & \multirow[b]{2}{*}{ S.D. } \\
\hline & \begin{tabular}{|c|} 
Minimum Range \\
of Applied \\
Negative Pressure \\
$\left(\mathrm{cm} . \mathrm{H}_{2} \mathrm{O}\right)$
\end{tabular} & $\begin{array}{l}\text { Maximum Range } \\
\text { of Applied } \\
\text { Negative Pressure } \\
\left(\mathrm{cm} . \mathrm{H}_{\mathbf{2}} \mathrm{O}\right)\end{array}$ & $\begin{array}{c}\text { Minimum } \\
\text { Corresponding } \\
\text { Balloon Range } \\
\left(\mathrm{cm} . \mathrm{H}_{2} \mathrm{O}\right)\end{array}$ & $\begin{array}{l}\text { Maximum } \\
\text { Corresponding } \\
\text { Balloon Range } \\
\left(\mathrm{cm} . \mathrm{H}_{2} \mathrm{O}\right)\end{array}$ & & & \\
\hline $\begin{array}{ll}\text { Mi. } & \ldots \\
\text { Mc. } & \ldots \\
\text { Ho. } & \ldots \\
\text { Dl. } & \ldots \\
\text { St. } & \ldots \\
\text { Be. } & \ldots \\
\text { G. } & \ldots \\
\text { Mo. } & \ldots \\
\text { Sc. } & \ldots \\
\text { Hu. } & \cdots\end{array}$ & $\begin{array}{l}0 \text { to }-9 \\
0 \text { to }-16 \\
0 \text { to }-22 \\
0 \text { to }-19 \cdot 5 \\
0 \text { to }-20 \\
0 \text { to }-15 \\
0 \text { to }-15 \\
0 \text { to }-14 \\
0 \text { to }-7 \\
0 \text { to }-8\end{array}$ & $\begin{array}{l}0 \text { to }-11 \\
0 \text { to }-32 \\
0 \text { to }-33 \\
0 \text { to }-28 \\
0 \text { to }-28 \\
0 \text { to }-39 \\
0 \text { to }-28 \\
0 \text { to }-21 \\
0 \text { to }-27 \\
0 \text { to }-17\end{array}$ & $\begin{array}{l}8 \\
14 \\
18 \\
16 \cdot 5 \\
18 \\
13 \cdot 5 \\
10 \\
12 \\
6 \cdot 5 \\
6\end{array}$ & $\begin{array}{l}10 \\
29 \\
26 \\
25 \cdot 5 \\
22 \cdot 5 \\
33 \cdot 5 \\
20 \\
18 \\
21 \\
12\end{array}$ & $\begin{array}{r}10 \\
9 \\
3 \\
13 \\
6 \\
9 \\
5 \\
7 \\
16 \\
2\end{array}$ & $\begin{array}{l}0.91 \\
0.81 \\
0.80 \\
0.87 \\
0.86 \\
0.90 \\
0.72 \\
0.90 \\
0.87 \\
0.75\end{array}$ & $\begin{array}{l}0.05 \\
0.07 \\
-\overline{0.03} \\
0.08 \\
0.0 \\
0.05 \\
0.04 \\
0.08 \\
-\end{array}$ \\
\hline
\end{tabular}

Mean B/J ratio of series 0.84. Range 0.72 to 0.91 . S.D. 0.06 .

T A B L E I I I

EFFECT OF POSITIVE JAR PRESSURES ION BRONCHIAL BALLOON PRESSURE AND BALLOON JAR PRESSURE RATIO

\begin{tabular}{|c|c|c|c|c|c|c|c|}
\hline \multirow[b]{2}{*}{ Subject } & \multicolumn{2}{|c|}{$\begin{array}{c}\text { Jar Pressure Range } \\
(\mathbf{J})\end{array}$} & \multicolumn{2}{|c|}{$\begin{array}{l}\text { Corresponding Bronchial Balloon } \\
\text { Pressure Range (B) }\end{array}$} & \multirow[b]{2}{*}{$\begin{array}{l}\text { No. of } \\
\text { Observations }\end{array}$} & \multirow{2}{*}{$\begin{array}{c}\text { Mean } \\
\text { B/J } \\
\text { Ratio }\end{array}$} & \multirow[b]{2}{*}{ S.D. } \\
\hline & \begin{tabular}{|c|} 
Minimum Range \\
of Applied \\
Positive Pressure \\
$\left(\mathrm{cm} . \mathrm{H}_{2} \mathrm{O}\right)$
\end{tabular} & $\begin{array}{l}\text { Maximum Range } \\
\text { of Applied } \\
\text { Positive Pressure } \\
\text { (cm. } \mathrm{H}_{2} \mathrm{O} \text { ) }\end{array}$ & $\begin{array}{l}\text { Minimum } \\
\text { Corresponding } \\
\text { Balloon Range } \\
\left(\mathrm{cm} . \mathrm{H}_{2} \mathrm{O}\right)\end{array}$ & $\begin{array}{l}\text { Maximum } \\
\text { Corresponding } \\
\text { Balloon Range } \\
\left(\mathrm{cm} . \mathrm{H}_{2} \mathrm{O}\right)\end{array}$ & & & \\
\hline $\begin{array}{ll}\text { Mc. } & \ldots \\
\text { Ho. } & \ldots \\
\text { G. } & \ldots \\
\text { Mo. } & \ldots \\
\text { Hu. } & \ldots\end{array}$ & $\begin{array}{l}0 \text { to }+13 \\
0 \text { to }+15 \\
0 \text { to }+13 \\
0 \text { to }+30 \\
0 \text { to }+23\end{array}$ & $\begin{array}{l}0 \text { to }+24 \\
0 \text { to }+16 \\
0 \text { to }+16 \\
0 \text { to }+56 \\
0 \text { to }+43\end{array}$ & $\begin{array}{l}12 \\
12 \\
12 \\
27 \\
13\end{array}$ & $\begin{array}{l}22 \\
14 \\
13 \\
55 \\
36\end{array}$ & $\begin{array}{r}7 \\
2 \\
2 \\
5 \\
17\end{array}$ & $\begin{array}{l}0.95 \\
0.80 \\
0.85 \\
0.92 \\
0.85\end{array}$ & $\begin{array}{l}0.0 \\
-\overline{-} \\
0.02 \\
0.04\end{array}$ \\
\hline
\end{tabular}

Mean B/J ratio of series 0.87 . Range 0.8 to 0.95 . S.D. 0.06 .

T A B L E I V

BRONCHIAL BALLOON/JAR PRESSURE RATIOS FOR FIVE LUNGS IN WHICH FULL RANGE OF NEGATIVE AND POSITIVE JAR PRESSURES WERE RECORDED

\begin{tabular}{|c|c|c|c|c|c|c|c|c|}
\hline \multicolumn{4}{|c|}{ Subject } & $\begin{array}{l}\text { Maximum } \\
\text { Range of } \\
\text { Jar Pressures } \\
\left(\mathrm{cm} . \mathrm{H}_{2} \mathrm{O}\right)\end{array}$ & $\begin{array}{c}\text { Maximum } \\
\text { Range of Bronchial } \\
\text { Balloon Pressures } \\
\left(\mathrm{cm} . \mathrm{H}_{2} \mathrm{O}\right)\end{array}$ & $\begin{array}{c}\text { (a) } \\
\text { Range } \\
\text { Jar Pressure } \\
\left(\mathrm{cm} . \mathrm{H}_{2} \mathrm{O}\right)\end{array}$ & $\begin{array}{c}\text { (b) } \\
\text { Range } \\
\text { Balloon Pressure } \\
\left(\mathrm{cm} . \mathrm{H}_{2} \mathrm{O}\right)\end{array}$ & $\underset{\mathbf{b} / \mathbf{a}}{\text { Ratio }}$ \\
\hline $\begin{array}{l}\text { Mc. } \\
\text { Ho. } \\
\text { Gl } \\
\text { Mo. } \\
\text { Hu. }\end{array}$ & $\begin{array}{l}\cdots \\
\cdots \\
\cdots \\
\cdots\end{array}$ & $\begin{array}{l}\cdots \\
\cdots \\
\cdots \\
\cdots\end{array}$ & $\begin{array}{l}\ldots \\
\cdots \\
\cdots \\
\ldots\end{array}$ & $\begin{array}{l}-32 \text { to }+24 \\
-33 \text { to }+16 \\
-28 \text { to }+22 \\
-21 \text { to }+56 \\
-17 \text { to }+43\end{array}$ & $\begin{array}{l}-29 \text { to }+22 \\
-26 \text { to }+14 \\
-20 \text { to }+20 \\
-18 \text { to }+53 \\
-12 \text { to }+36\end{array}$ & $\begin{array}{l}56 \\
49 \\
50 \\
77 \\
60\end{array}$ & $\begin{array}{l}51 \\
40 \\
40 \\
71 \\
48\end{array}$ & $\begin{array}{l}0.91 \\
0.82 \\
0.8 \\
0.92 \\
0.8\end{array}$ \\
\hline
\end{tabular}

Ratio $b / a=$ range 0.8 to 0.92 . Mean 0.85 .

IV). It was remarkably consistent over a considerable range of applied pressure $(-39$ to $+56 \mathrm{~cm}$. water). The ratio $B / J$ over the whole range of positive and negative pressures lay between 0.7 and 0.95 , with a mean of 0.85 (Table IV). The mean for negative applied pressures was 0.84 (Table II) and for positive pressures (Table III) 0.87 .

It will be noted that there is a simple pressure gradient from pleura to bronchus which is relatively small. Any pressure effect at the surface of the lung is mirrored accurately inside the bronchus. The balloon pressure excursion was a smaller but constant proportion of the applied pressure excursion (an example is shown in Fig. 3). When positive pressures were applied the $B / J$ ratio rose slightly. This would be expected under these conditions, as no force is being used to overcome elastic structures apart from the bronchial wall. 


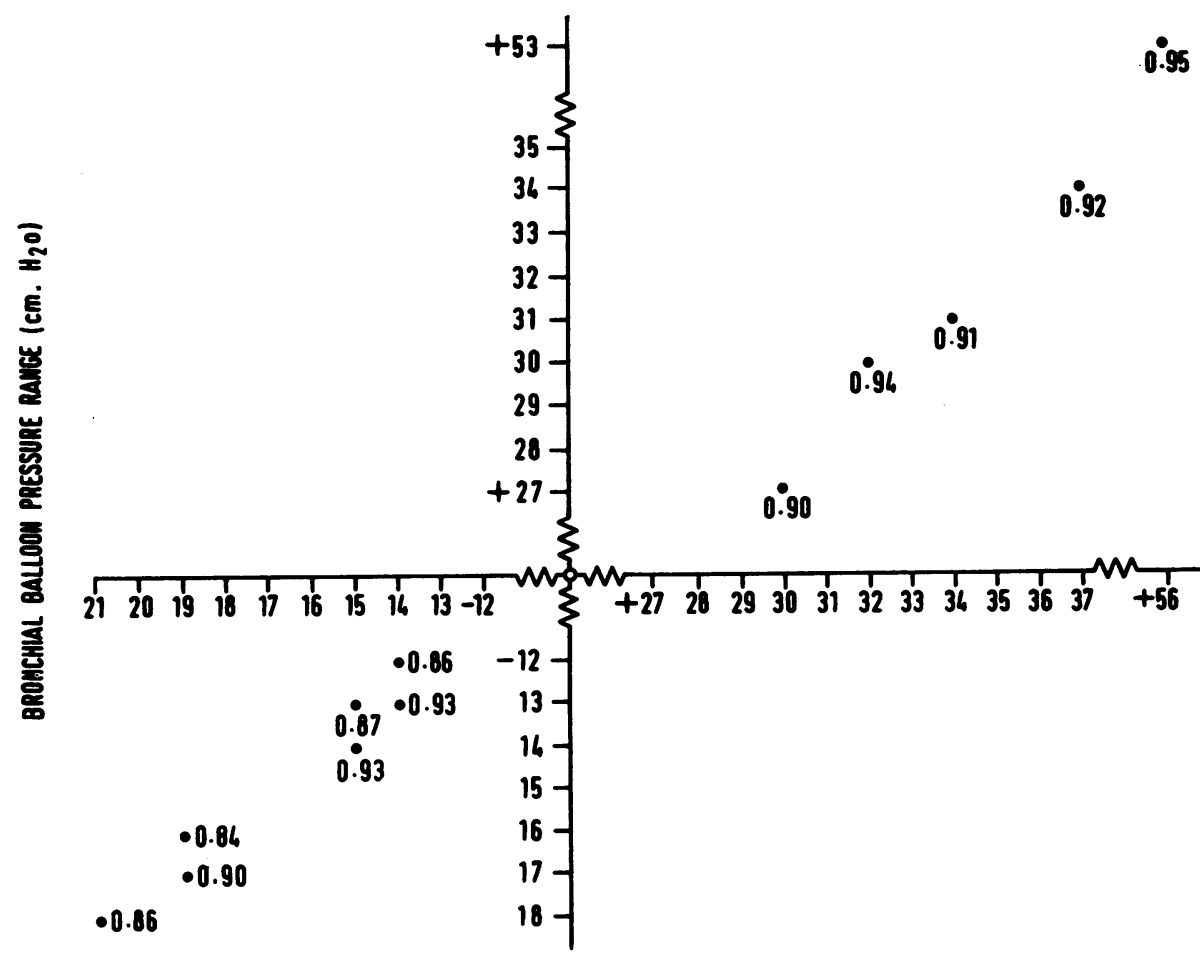

EXTERMAL APPLIEO PRESSURE RANGE (cm. $\left.\mathrm{H}_{2} \mathrm{O}\right)$

FIG. 3. Patient Mo. Relationship between external applied pressure ranges and those recorded by the balloon in the bronchus. Each point represents the applied pressure range and corresponding bronchial balloon pressure range. The figure beside each point is the ratio balloon pressure excursion/external applied pressure excursion.

Within the limits of error of the tracing run at a speed of $1 \mathrm{~cm} . / \mathrm{sec}$. the pressure changes were immediately recorded by the bronchial balloon. Sufficient time (up to $90 \mathrm{sec}$.), however, was given for air to enter the lung so as to increase the intra-alveolar pressure and ensure that a radial traction effect, if it occurred, was made possible and, secondly, that $B / J$ ratios of less than unity were not simply a reflection of a damping effect by unventilated lung around the probe.

A range of inflation pressures was employed (Table IV). The maximum obtained was limited by leaks at the higher pressures or by the lung inflating so much as to press on the lid of the jar. The rotation of the probe from vertical towards horizontal as the lung inflated appeared to make no appreciable difference to the results. This phenomenon was checked by a separate experiment changing the position of the probe and seeing if there was a pressure change from vertical to horizontal. There was no difference. In some of the lungs deflation was slower than inflation due to the presence of tumour and narrowing of the airways by the probe. This limited the rate of inflation in most specimens, though some responded quickly enough for rates of 20 per minute to be used.

Attempts were made in three cases (Dl., Mi., Be.) to measure the relative contribution of the bronchus and the lung parenchyma to the fall in pressure across the lung (Table $\mathrm{V}$ and Fig. 4). In these cases, in which the alveolar tissue was dissected away from the bronchus, the subsequent measurements showed a small increase of the $B / J$ ratio in two cases (no change in the other), although only one (D1.) was statistically significant (Table $\mathrm{V}$ and Fig. 4). The ratios obtained suggest that there is only a small fall in pressure across the lung tissue and bronchial wall and that the fall in pressure across the lung parenchyma itself is very small. Attempts were made to relate the $B / J$ ratio to the F.E.V. and the medical history (Table I), but no pattern emerged. 
T A B L E V

EFFECT OF NEGATIVE JAR PRESSURE ON BRONCHIAL BALLOON PRESSURE AND BALLOON/JAR PRESSURE RATIO BEFORE AND AFTER REMOVAL OF LUNG PARENCHYMA

\begin{tabular}{|c|c|c|c|c|c|c|c|}
\hline \multirow[b]{2}{*}{ Subject } & \multicolumn{2}{|c|}{$\underset{(J)}{\text { Jar Pressure Range }}$} & \multicolumn{2}{|c|}{$\begin{array}{c}\text { Corresponding Bronchial Balloon } \\
\text { Pressure Range (B) }\end{array}$} & \multirow[b]{2}{*}{$\begin{array}{l}\text { No. of } \\
\text { Observations }\end{array}$} & \multirow[b]{2}{*}{$\begin{array}{c}\text { Mean } \mathbf{B} / \mathbf{J} \\
\text { Ratio }\end{array}$} & \multirow[b]{2}{*}{$\begin{array}{c}\text { Statistical } \\
\text { Signifizance of } \\
\text { Difference of } \\
\text { Means ( } t \text {-test) }\end{array}$} \\
\hline & $\begin{array}{c}\text { Minimum Range } \\
\text { of Applied } \\
\text { Negative } \\
\text { Pressure } \\
\left(\mathrm{cm} . \mathrm{H}_{2} \mathrm{O}\right)\end{array}$ & $\begin{array}{c}\text { Maximum Range } \\
\text { of Applied } \\
\text { Negative } \\
\text { Pressure } \\
\left(\mathrm{cm} . \mathrm{H}_{2} \mathrm{O}\right)\end{array}$ & $\begin{array}{l}\text { Minimum } \\
\text { Corresponding } \\
\text { Balloon } \\
\text { Pressure Range } \\
\left(\mathrm{cm} . \mathrm{H}_{2} \mathrm{O}\right)\end{array}$ & $\begin{array}{l}\text { Maximum } \\
\text { Corresponding } \\
\text { Balloon } \\
\text { Pressure Range } \\
\left(\mathrm{cm} . \mathrm{H}_{\mathbf{2}} \mathrm{O}\right)\end{array}$ & & & \\
\hline $\begin{array}{l}\text { Be. } \\
\text { Before . } \\
\text { After . }\end{array}$ & $\begin{array}{l}0 \text { to }-15 \\
0 \text { to }-21\end{array}$ & $\begin{array}{l}0 \text { to }-39 \\
0 \text { to }-32 \\
\end{array}$ & $\begin{array}{l}13 \cdot 5 \\
19\end{array}$ & $\begin{array}{l}33 \cdot 5 \\
28 \cdot 5\end{array}$ & $\begin{array}{l}9 \\
9\end{array}$ & $\begin{array}{l}0.90 \\
0.90\end{array}$ & Not significant \\
\hline $\begin{array}{l}\text { Dl. } \\
\text { Before .. } \\
\text { After }\end{array}$ & $\begin{array}{l}0 \text { to }-19 \cdot 5 \\
0 \text { to }-16 \cdot 3\end{array}$ & $\begin{array}{l}0 \text { to }-29 \\
0 \text { to }-24\end{array}$ & $\begin{array}{l}16 \cdot 5 \\
16\end{array}$ & $\begin{array}{l}25 \cdot 5 \\
22 \cdot 7\end{array}$ & $\begin{array}{l}13 \\
12\end{array}$ & $\begin{array}{l}0 \cdot 87 \\
0.94\end{array}$ & $P<0.001$ \\
\hline $\begin{array}{l}\text { Mi. } \\
\text { Before .. } \\
\text { After .. }\end{array}$ & $\begin{array}{l}0 \text { to }-9 \\
0 \text { to }-13.5\end{array}$ & $\begin{array}{l}0 \text { to }-11 \\
0 \text { to }-15\end{array}$ & $\begin{array}{r}8 \\
12\end{array}$ & $\begin{array}{l}10 \\
13 \cdot 5\end{array}$ & $\begin{array}{r}10 \\
6\end{array}$ & $\begin{array}{l}0.91 \\
0.92\end{array}$ & Not significant \\
\hline
\end{tabular}

Before =lung intact. After=lung in which parenchyma had been stripped from bronchus containing probe.

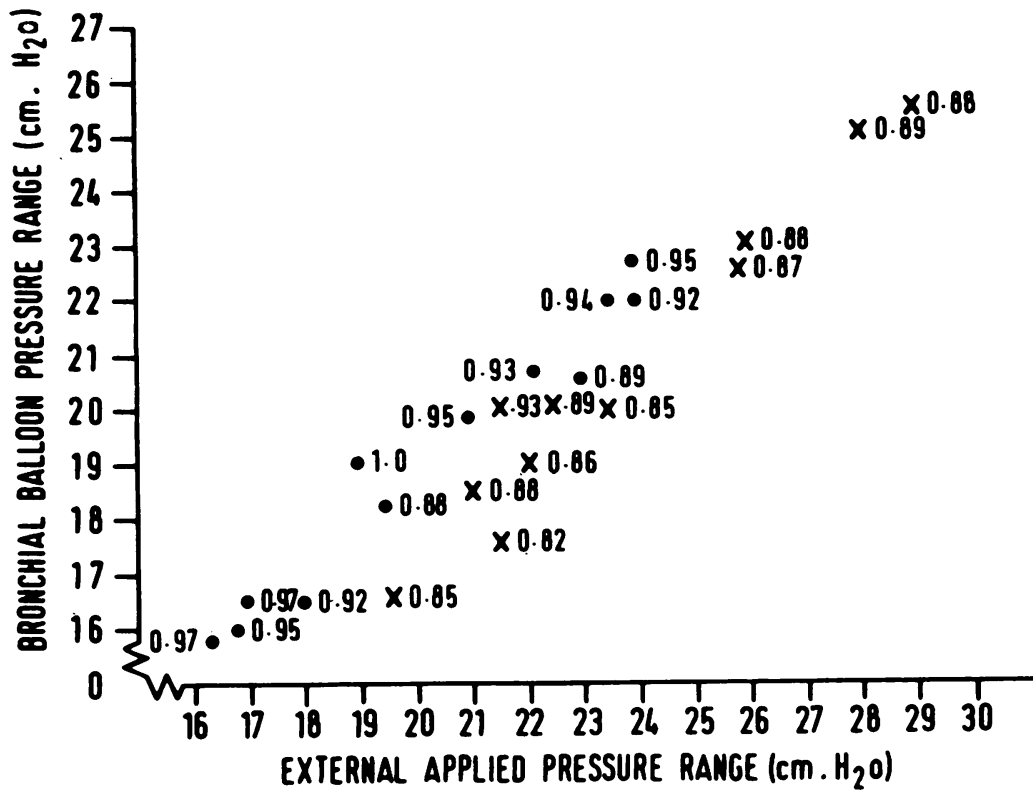

FIG. 4. Patient Dl. Relationship between the external applied pressure ranges and those recorded by the balloon in the bronchus. Each point represents the applied pressure range and corresponding bronchial balloon pressure range. The figure beside each point is the ratio balloon pressure excursion/external applied pressure excursion. $\times$ Bronchus with surrounding lung parenchyma. Bronchus without surrounding lung parenchyma.

\section{DISCUSSION}

If the hypothesis proposed by Howell and his colleagues (1961), referred to in our introductory paragraph, were applicable to the bronchus, it would be expected that the $B / J$ ratio would be above unity, but this was not found to be so in these experiments. Similarly, if there were a radial traction effect on the bronchus, removing the parenchyma should remove this and should then cause a lesser outward pull on the bronchial walls. A fall in the $B / J$ ratio should then result. 
This was not found and there was, therefore, no support in this study for a radial traction effect as proposed by Howell et al. (1961) in relation to bronchial movement in the size of bronchus investigated in this paper. Support for this conclusion was given in a recent paper by Hyatt and Flath (1966), who found no evidence of a radial traction effect in the isolated larger bronchi of dogs over small distending pressures. Howell's hypothesis suggests that the ratios between endomural bronchial pressure and oesophageal pressure should always be greater than unity, whereas in a number of cases studied by Douglas et al. (1966a) the ratio was less than unity.

In vivo studies by Douglas et al. have shown that 0.3 to 0.6 is a likely value in normal subjects for the ratio bronchial balloon pressure excursion/ oesophageal pressure excursion $(\mathrm{B} / \mathrm{O})$, the latter figure being perhaps the more likely. As these workers state, estimation of oesophageal pressure in the supine position probably overestimates the pleural pressure excursions and therefore underestimates the ratio between balloon and pleural pressure excursions. Also, lungs in vivo have tone, whereas some of this is presumably lost in the resected lung at room temperature. This would result in a higher $B / J$ ratio than in a corresponding viable lung because less force will be needed to overcome the tissue resistance when tone is absent. Further, the probe probably wedges further down the bronchial tree in the resected lung as the bronchus presumably dilates more readily if it has lost its normal tone. The bronchial wall at the site of the balloon may therefore be thinner and the pressure fall across it rather less than in the intact patient. Thus, making allowances for the differences in conditions, the figures we have recorded are reasonably consistent with those recorded by Crofton et al. (1963) and Douglas et al. (1966a) in relatively normal patients. Several of the patients in the series reported by Crofton et al. (1963) and Douglas et al. (1966a) have diseases (such as bronchitis) similar to those of the patients from whom the resected lungs were removed and yet they had much higher values of $\mathrm{B} / \mathrm{O}$ than unity. In some very wheezy patients the ratio was as high as three. This suggests that the living bronchial muscle has the ability to maintain an active state of contraction and may do so in pathological states. Douglas et al. (1966b) have speculated that in asthmatics increased stretch on the bronchial wall might induce a contraction coincident with $\overrightarrow{\bar{F}}$ expiration as a rebound phenomenon. There was $\overline{0}$ no evidence of this in the present study in so far as balloon pressure excursions returned to the base line and did not overshoot this line as might have been expected if there had been active contraction of the bronchus on expiration. There was, however, only one asthmatic in the series and the observations in this case were made 24 hours post mortem. Also, of course, all the specimens were outside the body and an in vivo effect of the type suggested cannot be completely excluded by these results.

The consistency of the results is somewhat $\overrightarrow{\dot{v}}$ surprising when one considers the material used. of The lungs were abnormal in several ways: (1) 오 most had tumour present; (2) there was back- $\vec{c}$ ground pathology from associated disease (Table و I) ; (3) bronchopneumonia and sputum retention were present in some of the cases of carcinoma of the bronchus; and (4) the resected specimens were subjected to trauma during handling at operation and after. However, in spite of all these imperfections the results correspond closely with what might be expected on a priori grounds.

The authors wish to thank Mr. R. J. M. McCormack and Mr. P. R. Walbaum, of the Thoracic Surgical Unit, City Hospital, Edinburgh, for providing the operation specimens, and Professor J. W. Crofton, Dr. A. C. Douglas, and Dr. D. C. Simpson for help and encouragement. They also thank Mr. C. Shepley, of the Edinburgh University Department of Medical Illustration, for Fig. 1 and the University Medical Photography Unit for the preparation of the remainder of the illustrations. They are grateful to the authors and the American Review of Respiratory Diseases for permission to reproduce Figure 2.

One of the authors (B.H.) was supported by a grant from the Medical Research Council, which also provided a grant for apparatus.

\section{REFERENCES}

Crofton, J., Douglas, A., Simpson, D., and Merchant, Sylvia (1963). The measurement of bronchial endomural or 'squeeze' pressure. O Thorax, 18, 68.

Douglas, A., Simpson, D., Merchant, Sylvia, Crompton, G., and $\mathcal{O}$ Crofton, J. (1966a). The measurement of endomural bronchial $\mathrm{N}$ (or 'squeeze') pressures in bronchitis and asthma. Amer. Rev. $\omega$ resp. Dis., 93, 693.

(1966b). The effect of antispasmodic drugs on the endomural bronchial (or 'squeeze') pressures in bronchitis and asthma. Ibid., 93, 703 .

Howell, J. B. L., Permutt, Solbert, Proctor, D. F., and Riley, R. L. (1961). Effect of inflation of the lung on different parts of pulmon- ary vascular bed. J. appl. Physiol., 16, 71 .

Hyatt, R. E., and Flath, B. E. (1966). Influence of lung parenchyma: on pressure-diameter behavior of dog bronchi. Ibid., 21. 1448 